\title{
PRESCHOOL EDUCATION: REALITIES AND PERSPECTIVES WITHIN MODERN PEDAGOGICAL DISCOURSE
}

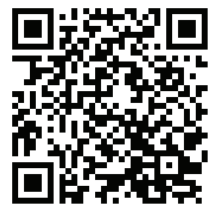

To cite this article:

\author{
Alla Bogush, Dr. Sc., Prof. \\ Chair holder, Chair of the Theory and Methods of Preschool \\ Education, \\ State Institution "K. D. Ushynsky South Ukrainian National \\ Pedagogical University", \\ Odesa, Ukraine \\ svrada@i.ua \\ https://orcid.org/0000-0002-5678-5455
}

\begin{abstract}
Bogush, A. (2018). Preschool education: realities and perspectives within modern pedagogical discourse. Education: Modern Discourses, 1, 151-160.

https://doi.org/10.32405/2617-3107-2018-1-14
\end{abstract}

\begin{abstract}
The article describes the phenomenon "preparatory (preschool) education" in the modern educational space, its realities and perspectives in the framework of the Concept of the "New Ukrainian School". The aim of the article is a scientific analysis of different views on the content of the senior pre-schoolers' training for schooling in connection with the transition of the school age starting point - the beginning of schooling at the age of six. The problem of continuity and perspectives in the continuous education system in Ukraine is considered. Continuity is understood as a sequential process which precedes the following one, based on the interconnected transition of the object directly from one state to another, which contributes to the lytic development of the child during the transitional age periods. The necessity of inheriting the activitycentred and communicative approaches to the organization of the child's vital activity by the school at the preschool level is grounded in order to prevent children's mental over freight. The necessity to single out an intermediate link between preschool and primary education - preparatory (preschool) education - at the state level is proved. The author interprets the phenomenon of "preparatory (preschool) education" as an intermediate link between preschool and primary education, which is associated with a special (knowledge, abilities and skills absorption) and a general (children's readiness to study at school) training with all its components (motivational, volitional, intellectual, communicative, linguistic, physical) which takes place at the positive, emotional background of the teacher children relationship with an orientation towards the person-targeted activity and communicative approaches which should be preserved in the first class (grade) as well. The aim of preparatory (preschool) education is to create appropriate conditions which would facilitate the equalization of starting opportunities for children constituting different social groups and layers for their further successful schooling.

Key words: state standards; five-year-old children; preschool education; institution of preschool education; continuity; preparatory (preschool) education; perspectives; primary education; succession.
\end{abstract}




\section{INTRODUCTION. PROBLEM STATEMENT}

Ukraine's coming into being as a sovereign state as well as its transformation into a civil society have predetermined radical reformation and modernization of the education system and changes of the main paradigms at all its levels. The above mentioned stipulate the importance of the preschool education as the starting point of the comprehensive education system.

The major principles of the modern Ukrainian preschool education system are declared in the list of the normative and strategic documents: "National Development Strategy of Ukraine's Education for the Period of 2012-2020", Laws of Ukraine "On Preschool Education", "On Protection of Childhood", Basic component of Preschool Education (BCPE), Development Concept of the "New Ukrainian School", strategic directions of building up education in Ukraine in which the necessity of scientific background of the modernization processes taking place within the state system of education regarding its compliance with current global tends is substantiated. While performing the set tasks related to the development of the education contents, historical review allows us to escape from making mistakes, to reveal achievements, to reserve and multiply its achievements, to comprehend modern achievements and to blueprint the future.

At the beginning of the $21^{\text {th }}$ century, significant changes in the attitudes towards the sphere "the content of preschool education" took place in the global space educational. In October 2010, the UNESCO World Conference on Early Childhood Care and Education was held in which 137 countries participated. The resolution of the forum noted: the foundation of education and its fundamentals are laid at preschool age.

Consequently, a new trend for the scientific research regarding the preschool education content has been determined. If at the end of the 20 century the views of scientists were aimed at the development of variational programs and personoriented methods of educational work with pre-schoolers, today the direction of the experimental study of continuity and viability in the content, methods, forms, technologies of education in preschool and primary schools have become a priority.

\section{LITERATURE REVIEW}

The scholars (Yu. Arkin, N. Bibik, O. Bohinich, D. Elkonin, L. Kalmykova, V. Kotyrlo, Z. Lebedieva, O. Savchenko, A. Usova M. Vashulenko, L. Wenger, L. Vygotsky, O. Zaporozhets and others) acutely discussed the designated problem in the twentieth century; in the XXI"st century its study continued (A. Bogush, O. Dubohay, N. Havrysh, L. Kalmykova, K. Krutiy, N. Shylina, T. Stepanova, S. Zamrozevych and others).

Theoretical positions have been developed, experimental research has been carried out; however, the problem has not only been solved, it has remained unsolved and has become especially acute today. The analysis of pedagogical practice has shown a number of negative moments that are impeding the positive solution of this urgent problem of the present days. The following can be singled out: the orientation towards one-sided adaptation of the establishments of preschool education to the goals, objectives and requirements of primary school; there is no differentiated approach to different systems of preschool and primary education, which is unacceptable under conditions of the variability of education. 
Even today there is observed a substitution of the general task of the continuity of the first two levels of education by a more narrow program of preparing children for school; the laws of children's mental development, the age-related sensitivity of the formation of various mental functions and qualitative neoformations are ignored; preschoolers and junior schoolchildren undergo "artificial acceleration", which stimulates unacceptable "maturation" of preschool education.

Unfortunately, the preparation of children for school was mainly aimed at developing solely subject-focused knowledge, skills and abilities, which led to duplication of the content, forms and methods of school education, which not only reduces children's interest to study, but also does harm to their health.

It should be noted that in popular practice, there are different approaches to understanding the implementation of continuity between establishments of preschool education and primary school used by both preschool educators and teachers of elementary school. For primary school teachers continuity is, uppermost, the presence of a certain amount of knowledge, skills and abilities before entering school; teachers do not take into account children's psychological readiness for school. For preschool educators the continuity, above all, is the concern that the children, who are to come to school, should obtain no complaints about them for feeling comfortable (Bohuslavska, 2009).

If we turn towards the modern pedagogical science, we will see that in the scientific circulation there are such concepts as "continuity of education", "continuity and perspectives in the work of a preschool education establishment and that one of the first year in primary school", "continuity", "readiness", although the semantic content the designated terms coincides with the one of "training / preparing children for school". The phenomenon "preschool education" has been introduced into scientific circulation.

Thus, there was a need to find out the modern view of the problem called "preparing / training children for school" within the Concept of the "New Ukrainian School" and the place of preschool education in it.

It should be noted that under our supervision the first doctoral degree research in two directions was carried out in Ukraine: a) the transformation of the preschool education content in the history of the development of domestic preschool pedagogy: methodology, theory, practice (the end of the nineteenth and twentieth centuries) (Stepanova, $2011)$; b) theoretical and methodical principles of preschool education targeted to fiveyear-old children (Kovshar, 2016).

\section{METHODOLOGY}

Methodology provides, first of all, for a categorical analysis of the key concepts as "continuity", "perspectives", "preparation / training for school", "preschool education" and the identification of existing contradictions in the theory and practice of preschool education.

The analysis of the psychological and pedagogical scientific fund containing educational and methodical support of preschool education as well as practice has testified to the presence of a number of contradictions that require urgent solution, to be more precise, the contradictions between:

- a new strategic course on ensuring the continuity of education, defined in state documents, and the lack of scientific research on the creation of appropriate socio-psychological, organizational and pedagogical conditions for its implementation; 
- social orders for the introduction of compulsory preschool education for the children aged five and the real state of the training targeted to senior pre-schoolers for schooling;

- an urgent need for modern pedagogical practice in the system of preschool and primary education based on the positive and progressive experience of training senior pre-schoolers for school and insufficient study of the previous historical and pedagogical experience which contains approaches to the solution of the problem dealing with the preschool education content;

- the need to develop a new content for the education and upbringing of five-yearold children (preschool education) and innovative technologies alongside with its implementation and the current state of educators' preparedness (proficiency) for such activities;

- the need to consolidate and integrate the efforts of preschool institutions, primary schools, the public and parents in creating conditions for training (preparing) senior pre-schoolers for schooling and the lack of scientific, educational and methodological support for preschool education (Kovshar, 2016).

\section{MAIN RESULTS}

It should be noted that preschool education is a component of general continuing education, which is understood as a multicomponent entity, the effectiveness of which depends on the implementation of its factors, such as continuity, perspectivity and readiness. In this sense, continuing education opens up opportunities for achieving integrity and continuity in education and upbringing, transforming education into a process that lasts for life. Continuity, according to dictionaries, is a sequential process that precedes the following one, based on the interconnected transition of an object directly from one state into another.

The continuity (succession) between the preschool and primary levels of education, according to T. Bohuslavska, is, firstly: the definition of general and specific educational goals at these stages, the construction of a single content line that will ensure an efficient, progressive development of the child, his / her successful transition to the next stage of education; secondly, it is the connection and consistency of each component of the methodological system (goals, tasks, content, methods, forms, means of organization) both in the institution of preschool education and primary school (Bohuslavska, 2009). We consider continuity as the class teachers' awareness of the programs and methods aimed at teaching and upbringing children in the institution of preschool education, the results of children's development, training and upbringing in all sections of the program as well as taking them into account in the further work of primary school. We should note that such an interpretation is not new in pedagogical circulation, it has been popular on the pages of the pedagogical press for several decades and is acute especially today, all pages of pedagogical journals contain this interpretation. The leading function of continuity is the provision of the child's lytic (according to L. Vygotsky's terminology) development during the transitional age periods. This is the continuity that prevents crisis phenomena in person's mental development.

How is the principle of continuity implemented between the first, preschool childhood, and the second one - the education of children at primary school? Unfortunately, today it is difficult to name at least any aspects of the implementation of this principle. 
We should mention that the continuity and perspectives are not included into the content of children's as well as students' upbringing and education in the state standards of education, its preschool and primary units (State Standards of Primary Education and Basic component of Preschool Education). Each of the documents developed is scientists' significant work and it deserves approval. Furthermore, none of them takes into account any achievements in the development, education and upbringing of children at their first 6-7 years, nor the prospects of what the children will meet in the second childhood. Programs and textbooks for the first class do not take into account the level of development of the five- (six-) year-old children, and this is the whole period of the first childhood. The Basic Component of Preschool Education and variational programs of preschool institutions do not take into account the content lines of the State Standard of Primary Education and elementary school programs. As a result, certain content lines of education and upbringing of pre-schoolers are overloaded with complex and unnecessary for this age "knowledge, skills and abilities". The continuity and perspectives in the relationships within the system "an educator - a child", "a child - an educator" and "a teacher - a student", "a student - a teacher" are not observed, the lack of such continuity in the relationship with the six-year-old children might seem especially dangerous, and this aspect is the one towards which the efforts of both educators and teachers should be directed. We are inclined to consider continuity as assimilation of the system of relationships "a pedagogue - a child", "a child - a teacher" by the school activity as well as the communicative aspects of the child's life at his / her preschool stage.

The activity-targeted aspect involves the preservation of preschool children's unique leading activity, with its gradual complication and a lytic transition to a new, more complicated educational activity which requires arbitrariness of all mental processes from the child.

The communicative aspect involves preserving the teacher - pupil's personal and intimate communication with the pupils during the first stages, this is a tenderly-trusting, humane attitude towards the child who has just entered the new collective and entered into a new social position called "a pupil", "a schoolboy". It presupposes child's gradual recalling to the awareness of his / her new social position in which the system of relations "a child - an educator" alters (it was dominant at the stage of pre-school childhood) as well as to the priority of the system "a teacher - a student", with the gradual orientation of pre-school establishments leavers on the personality of the teacher as the core of personal and business communication in school education.

Consequently, the continuity and perspectives of the development of the child's personality during the first two periods of childhood (preschool and primary units) implies a change in the types of joint activities performed by the child and the adult. V. Kudriavtsev distinguishes three types of joint activities performed by the child and the adult, which have different impacts on the child's mental development (Kudriavtsev, 1999).

The first type is reproductive, built on the instruction-fulfilment basis. An adult, for a child, acts only as a carrier of a socially specified amount of "KSAs (knowledge, skills, abilities)" which a child must necessarily acquire through copying and imitation under the teacher's direct control (Kudriavtsev, 1999).

The second type of collaborative activity is quasi-heuristic. An adult remains a carrier of "KSAs", though he / she tries to create a quasi-problem for a child, and inspires a child with those ways facilitating the solution of an educational task which he / she 
herself / himself knows well. However, within this type of joint activity, there is no real communication between a child and an adult either.

Finally, the third developing type of joint activity involves open problem for both the child and the teacher; there is a situation of uncertainty, it presupposes a search for solutions to it, which involves developing communication between the teacher and the child, the formation of both child's and teacher's abilities that they lacked. Such developing communication leads to self-development, to the formation of both teacher's and child's creative personality. This formula might seem effective for the third type of joint activity: "Do it together", "Do it with me", "Do it better than me", which corresponds to the humanistic paradigm of education.

Consequently, continuity and perspectives should include the orientation of preschool educators and class teachers towards the third developing type - joint activity with children, which takes into account children's age individuality, induces the child to creative self-expression, preserves the uniqueness and identity of preschool childhood, provides a lytic, crisis-free transition of pre-schoolers into the position of the personality representing the second childhood and at the same time reflects the developmental nature of education. I should note that this aspect of continuity is completely missing in the Basic component of Preschool Education and State Standards of Primary Education.

Moreover, we cannot speak about effective, full-fledged preparation (training) of children for schooling, if we do not take into account a child's psychological aspect, that is, the state of internal readiness of the child to transition to a new social position "a schoolboy / a schoolgirl", into a new social educational space of development called "school". Readiness is a conscious state of an organism to the perception of a certain new activity, new information that prevents the occurrence of crisis phenomena.

Children's psychological readiness for school involves the formation of their certain attitude towards schooling (as a serious and socially significant activity), that is, an appropriate motivation for learning, or motivational readiness, as well as provision of the necessary level of child's intellectual, speech and emotional and voluntary development (Kotyrlo, 1977).

No one can deny that when preparing / training children for schooling, one should avoid excessive overload of pre-schoolers with information data (taken from different educational sectors) which do not meet children's potential age capacity to assimilate them. For example, we mean the knowledge of Physics, Mathematics, Reading and Writing, Geometry, History, Astronomy, Geography, Valeology (Healthy lifestyle), Anatomy and Physiology, etc., which variational programs of preschool establishments, as well as the BCPE, are filled with today. One can hear more often today that our children are accelerators, they have considerable potential for learning complex material, and the only thing to do is to develop appropriate teaching methods. The denial of this assumption is contained in the words of V. Kotyrlo: "there is no direct or unambiguous dependence of development on learning” (Kotyrlo, 1977).

The educational effect of learning depends on its content and methods, in other words, what they are taught and how they are taught, whereas the content and methods of teaching are limited mandatory by children's age capacities, and while selecting the content of learning, in no case can we ignore the child's age, because, figuratively speaking, "The age problem that we have pushed outdoors is knocking at the window". It is impossible to teach children everything that adults want and what they can teach; it is important that the knowledge acquired contributes to the development of the child rather than being 
"dead load" or mechanically reproduced, we do not need the child to be like an automatic device which would give out what was programmed in it (Kotyrlo, 1977).

The problem of preparing / training children for schooling has become extremely relevant in the $21^{\text {th }}$ century, due to the modernization and reforming of Ukraine's education system, the transition to the school education which children start at the age of 6 . In this regard, extremely dangerous for children's health is their staying (studying) in one and the same first grade, since children constitute different age groups ranging from 5 years 9-10 months to 7,5 years of age. Children demonstrate diverse degrees of psychological readiness for education, different levels of pedagogical preparation for schooling: children who have their families (this group constitutes the majority - 60\%), children from different types of preschool education establishments (state, private, profile, etc.), children who were not prepared / trained for schooling or who were prepared / trained in compliance with elite programs.

A non-differential approach to children, their unification into the general category "a student", "a first-grader" delay children's adaptation to new school conditions and lead to nervous breakdowns and crisis phenomena.

Note that the experience of the Eighties of the $20^{\text {th }}$ century to send six-year-old children to preparatory classes was unsuccessful, they could not create conditions for children that would correspond to the age of these children: daytime sleep, feeding. Although today it turns out that the above mentioned factors are not necessary for sixyear-old children at all because at the state level it is allowed to found "corporate institutions of preschool education" in residential premises, houses on the ground floor, and enterprises.

The introduction of schooling for children aged 6 resulted into the closure of preparatory groups in preschool establishments and again there arose a problem: those children who, due to their health conditions, could not begin systematic schooling faced difficulties. Particularly affected by this were the children who, for various reasons, did not attend kindergartens, those who were brought up in families, at their grandparents'. At the same time, the lack of reception classes (the seven-year-olds) at preschool education establishments induced six-year-old children to return to the senior preschool groups (the six-year-olds) for a refresher "course", which adversely affected the formation of children's interest in school and "discouraged" them from studying. There is a serious problem of preparing five-year-old children for schooling. As a result, in 2010, the Law of Ukraine "On Preschool Education" regarding compulsory preschool education starting from the age of five was amended. Thus, Ukraine has embarked on the path of educational innovations, in fact, there appeared another, intermediate, layer at the legislative level - preschool education (reception classes), which requires its reconsideration, solution of a number of issues related to organization, and programing and methodology.

We shall, first of all, define the concept of "school preparatory education" which has both a broad and a narrow understanding. In the broad sense, "school preparatory education" covers the upbringing and development of young children and pre-schoolers in different cells: in a family, in a preschool institution, in various children's development and education centres alongside with children's short-term preparation for schooling at secondary schools, that is, all social institutions, where a child may stay before going to school, up to the age of six.

As for a more narrow understanding of the phenomenon "school preparatory education", there can be also mentioned different approaches. 
First of all, school preparatory education is understood as the preparation targeted to the child of preschool age for schooling in preschool education institutions and in groups at schools in order to provide a lytic non-crisis development of the child, that is, keeping to the principle of continuity and perspectives at all levels of educational work of preschool establishments and that one of the first grade (class) at school.

Secondly, due to the fact that there was almost a $40 \%$ reduction of the number of children attending a preschool education establishment (PEE) compared with 1990; the majority of children aged six are not prepared for schooling. Therefore, in the first class (grade), there is observed a diversity of pupils in their age, knowledge and behaviour. Both pupils and teachers suffer in this situation.

In Ukraine, some attempts to create compulsory groups of all children aged five have been made at comprehensive schools (CS) in order to solve the problem in this way and prepare children for schooling, including consideration of continuity and perspectivity. Today it is a debatable issue. It raises a whole range of questions and problems, as follows: where to hold these children, who will work with them, how to solve the problem of daytime sleep and feeding, etc.; and most important thing is that the designated groups at schools are the classes that will mostly duplicate the first-grade program.

My vision of how to solve the problem of preschool education is: to open and build new PEEs that would allow the majority of five-year-old children (about 90\%); to open complex PEE-SCs and SC-PEEs, in which the senior preschool group would consist of even-aged children - the sixth year of life; whereas a smaller percentage of children who, for various reasons, will not attend preschool establishments may attend short-term groups for preparing / training children for schooling at these complexes or in centres where both preschool teachers and primary school teachers will be involved.

And only then can we review the state standards and program requirements in order to avoid overloading preschool children with unnecessary knowledge, skills and abilities, as well as from reviewing what the children learned in preschool groups in the first class (grade). We will express our vision concerning the phenomenon of preparatory (preschool) education.

We understand preparatory (preschool) education as an intermediate link between preschool and primary education, which is associated with a special (knowledge, abilities and skills absorption) and a general (children's readiness to study at school) training with all its components (motivational, volitional, intellectual, communicative, linguistic, physical) which takes place at the positive, emotional background of the teacher children relationship with an orientation towards the person-targeted activity and communicative approaches which should be preserved in the first class (grade) as well.

Preparatory (preschool) education is a purposeful, organized process and the result of the development, education and training of senior pre-schoolers in various social institutions; its purpose is to create conditions facilitating equalization of starting opportunities for children constituting different social groups and layers for their further successful schooling. It is an integral part of continuing education, an intermediate link between family education, preschool and primary levels of education in the general, continuous system of education, it performs the function of social control over the state of children's physical, mental, intellectual, moral, ethical, emotional and voluntary development before they enter school (Bogush, 2013; Stepanova, 2011).

The content of preparatory (preschool) education is a holistic pedagogical system of society's requirements set to the training of preschoolers' for schooling; this system 
is adapted to age peculiarities of the senior preschoolers; a system of minimal necessary knowledge, skills and abilities as well as methods of conducting activities typical of the children aged six - seven for their further study at school, which provides for their psychological readiness and education at school, the formation of children's key competencies in accordance with the Basic Component of Pre-School Education (Bogush, 2013; Stepanova, 2011).

\section{CONCLUSIONS}

A new approach to the organization of preparatory (preschool) education in Ukraine will ensure: at the preschool level - the preservation of the value of the preschool age, the cognitive and personal development of the child, of his / her readiness to interact with social environment, the development of a leading activity as a fundamental formation of the preschool period. At the level of primary school - it presupposes taking into account the existing level of the achievements within pre-school childhood; individual work in cases of child's intensive development; special assistance in correcting unformed qualities when a pre-schooler; the development of the leading activity as a fundamental formation of junior schoolchildren and the perspective development of the leading activities and forms of communication and interaction with the environment (Bogush, 2011). The prospect of further research is seen in the development of the content, forms and methods: innovative technologies for teaching five-year-old children with a focus on the modern paradigm of education, both in Ukraine and in world experience.

\section{REFERENCES}

Boguslavska, T. M (2009). Variatyvni kontseptsii nastupnosti doshkilnoi i pochatkovoi lanok osvity (u vitchyznianii pedahohitsi XXI st.) [Variative concepts of the continuity of preschool and primary education levels (in the national pedagogy of the XXI century)]. Nauchno-metodicheskij zhurnal "Psihologo-pedagogicheskij poisk", 1 (9), 122-127.

Bogush, A. M. (2011). Peredshkilna osvita: realii sohodennia [Preparatory education: today's realities]. Pedahohichni nauky, LVIII (Vol. 1), 11-16.

Bogush, A. \& Malinovska, N. (2013). Pershi kroky hramoty: peredshkilnyi vik: navch. posibnyk [First steps of reading and writing: preschool age]. Kyiv: Slovo, 56-61. (in Ukrainian)

Bogush, A. M. (2010). Peredshkilna osvita: nastupnist doshkilnoi i pochatkovoi lanok osvity yak pedahohichna problema [Pre-school education: the continuity of preschool and primary education units as a pedagogical problem]. Obrii, 2 (31).

Bogush, A. M. (2011). Vytoky peredshkilnoi osvity v pedahohichnomu vymiri V. Sukhomlynskoho: realii i perspektyvy [Origins of pre-school education in pedagogical dimensions of V. Sukhomlynskyi: realities and perspectives]. Pedahohichnyi dyskurs, 10, 89-96.

Kalmykova, L. O. (2000). Suchasni problemy nastupnosti y perspektyvnosti ta shliakhy yikh uprovadzhennia [Modern issues on continuity and perspectivity and ways of their introduction]. Dytynstvo: Nastupnist i perspektyvnist. [Childhood: continuity and perspectivity]. Pereyaslav-Khmelnytskyi, 132-141.

Kovshar, O. V. (2016). Teoretyko-metodychni zasady orhanizatsii peredshkilnoi osvity ditei piaty rokiv [Theoretical and methodical principles of organization of pre-school education targeted to five-year-old children] (Extended abstract of Doctor's thesis). Odesa. 
Kotyrlo, V. K. (1977). Zavtra v shkolu [We have school tomorrow]. Kyiv: Radianska shkola. (in Russian)

Kudriavtsev, V. T. (1999). Psihologiya razvitiya cheloveka [Psychology of person's development]. Riga: Eksperiment.

Kudriavtsev, V. T. (ed.). (2001). Preemstvennost' stupenej v sisteme razvivayushchego i razvivayushchegosya obrazovaniya [The continuity of stages in the system of developing education]. Moscow.

Stepanova, T. M. (2011). Transformaciï zmistu peredshkil'noï osviti v istoriï rozvitku vitchiznyanoï doshkil'noï pedagogiki: metodologiya, teoriya, praktika (kinec' XIX - XX st.) [Content transformation of preparatory education in the history of development of domestic preschool Pedagogy: methodology, theory, practice (the end of the nineteenth - twentieth centuries)]. (Extended abstract of Doctor's thesis). Odessa. 